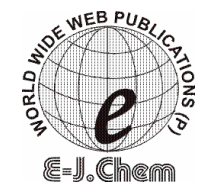

http://www.e-journals.net
ISSN: 0973-4945; CODEN ECJHAO

E-Journal of Chemistry

Vol. 5, No. 1, pp. 93-99, January 2008

\title{
A New Spectrophotometric Method for Hydrogen Sulphide Through Electrolytically Generated Mn(III) With $O$-Tolidine
}

\author{
M.S SURESHA, MANSOUR S. ABDUL GALIL, MAHADEVAIAH, \\ M.A.SATHISH, M.S.YOGENDRA KUMAR and G.NAGENDRAPPA* \\ Department of Studies in Chemistry, \\ University of Mysore, Mysore 570006. \\ gnagendrappa@yahoo.co.in
}

Received 18 May 2007; Accepted 10 July 2007

\begin{abstract}
A simple, sensitive and economical spectrophotometric method for the determination of hydrogen sulphide is developed. The method is based on a redox reaction in that $\mathrm{Mn}$ (III) generated electrolytically is taken in excess, which is oxidizing a known but a less quantity of hydrogen sulphide and the unreacted oxidant will oxidize further $o$-tolidine to produce an orange yellow quinonediimine absorbing cation ( $\lambda$ max. $455 \mathrm{~nm}$ ). Therefore, in principle, the decrease in color intensity of the absorbing system is proportional to the concentration of hydrogen sulphide. The stoichiometry between $\mathrm{Mn}$ (III) and $o$-tolidine and stability constant of the complex were determined by Job's continuous method, the corresponding values were found to be $2: 1$ and $1.42 \mathrm{X}$ $10^{5} \mathrm{Lmol}^{-1}$. The system was obeying Lambert-Beer's law in the range 0.2-1.4 $\mu \mathrm{g} \mathrm{mL}^{-1}$ of hydrogen sulphide. Molar absorptivity, correlation coefficient and Sandell's sensitivity values were also calculated and found to be $4.2062 \times 10^{3}$ $\mathrm{L} \mathrm{mol}^{-1} \mathrm{~cm}^{-1}, 0.999$ and $0.0012 \mu \mathrm{g} \mathrm{cm}^{-2}$ respectively. The method was employed for the determination of hydrogen sulphide in water samples. The results obtained were reproducible with acceptable standard deviation 0.010.068 and relative standard deviation, less than $3.21 \%$. For a comparison, hydrogen sulphide present in water samples were also determined separately following the methylene blue official method. The results of the proposed method compare well with the official method.
\end{abstract}

Keywords: Hydrogen sulphide, Redox reaction, Spectrophotometry, Mn(III), o-Tolidine. 


\section{Introduction}

Hydrogen sulfide is one of the end products resulting from the action of many varieties of bacteria on organic material containing protein ${ }^{1}$. Though the presence in protein of sulfurcontaining compounds other than cysteine has been hinted at, it is generally recognized that this amino acid is the chief source of hydrogen sulfide formed during the putrefaction of flesh products ${ }^{1}$. Hydrogen sulfide and sulfides of alkali and alkaline earth metals are soluble in water ${ }^{2}$. Soluble sulphide salts dissociate in to sulphide ions that react with the hydrogen ions in water to form the hydrogen sulphide ion (HS-) or hydrogen sulphide. The relative concentrations of these species are a function of the $\mathrm{pH}$ of the water; hydrogen sulphide concentration increases with decreasing $\mathrm{pH}^{3,4}$ The oral ingestion of alkali sulphide has been reported to cause nausea, vomiting and epigastric pain as well as irritate the mucous membrane. It has been estimated that an oral dose 10 to $15 \mathrm{~g}$ sodium sulphide would be fatal to human. ${ }^{5,6}$ Hydrogen sulphide is considered as an air pollutant due to its toxicity, unpleasant odour and extreme reactivity with metals ${ }^{7}$.

Hydrogen sulphide released by industrial process and by the decay of organic matter by microbial action, on land as well as in water, is one of the major compounds involved in the environmental sulphur cycle ${ }^{8}$. The main industrial sources of hydrogen sulphide are kraft pulp mills, petroleum refineries, the gasification of coal, meat processing plants and sewage treatment plants ${ }^{9}$. In addition, it is frequently used as a reagent or generated as a by-product in industrial process. Due to the increasing environmental concern for chemical discharges, the sulphide content in industrial effluents must be continuously controlled. ${ }^{10}$ From the environmental point of view, sulphide is currently regarded as a key parameter in assessing the environmental quality of a given system, since hydrogen sulphide controls the bioavailability of heavy metals in anoxic environments ${ }^{10}$. There are several established methods available for the determination of hydrogen sulphide in various sources, for example wastewater ${ }^{11-14}$, air ${ }^{15-17}$ and biogas. ${ }^{18}$ Among them methylene blue method is widely used for the determination of hydrogen sulphide trapped in cadmium salt solution ${ }^{19}$ or $1 \%$ zinc acetate solution ${ }^{20}$ Lodge and Pate ${ }^{21}$ reported that the results obtained by methylene blue method were erratic when trapped in cadmium salt solution. Daniel and Robert ${ }^{22}$ showed that zinc acetate is a better absorbent than cadmium salts for the determination of hydrogen sulphide. But the present method is based on redox reaction in that $\mathrm{Mn}(\mathrm{III})$ generated electrolytically ${ }^{22-24}$ is taken in excess, is oxidizing a known but very less quantity of hydrogen sulphide to sulphate ${ }^{35}$ and the unreacted oxidant will oxidize further $o$-tolidine to an orange yellow color qunonediimine absorbing cation $^{25}$. Therefore, in principle, the decrease in color intensity of the system in that condition is proportional to the concentration of hydrogen sulphide.

\section{Experimental}

Elico spectrophotometer, model SL171 (Hyderabad, India) with $1 \mathrm{~cm}$ matched quartz cells, UV-visible-spectrophotometer (Shimadzu), Acculab digital balance readable 0.0001g and UV spectrophotometer (Jena, Germany) were used.

\section{Reagents and solutions}

All chemicals used in the experiment were of analytical reagent grade and the water used was distilled water. 


\section{Preparation of Manganese(III) solution}

$10 \mathrm{~mL}$ of $2 \mathrm{M}$ manganese(II) sulphate solution was diluted to about $100 \mathrm{~mL}$ with $5 \mathrm{M}$ sulfuric acid and electrolyzed the solution for about $2 \mathrm{~h}^{23-24}$. Concentration of the prepared $\mathrm{Mn}$ (III) solution was standardized iodimetrically ${ }^{26}$ and the solution was found to be $0.015 \mathrm{M}$ with respect to $\mathrm{Mn}(\mathrm{III})$. From that an aliquot, $1.3 \mathrm{~mL}$ was further diluted to $100 \mathrm{~mL}$ in a volumetric flask with $5 \mathrm{M}$ sulfuric acid, the solution so obtained was $0.0002 \mathrm{M}$ (cal.)

\section{Preparation of standard o-tolidine solution}

Accurately weighed amount, $20 \mathrm{mg}$ of o-tolidine sample was dissolved in a clean beaker containing about $10 \mathrm{~mL}$ of ethanol and the solution was transferred into a $100 \mathrm{~mL}$ volumetric flask. The beaker was washed with water and washings were also transferred into the flask. Then the solution was diluted to mark with water. The prepared solution was $0.001 \mathrm{M}$ (cal.) from that solution, an aliquot of $10 \mathrm{~mL}$ was further diluted to $50 \mathrm{~mL}$ with water to obtain $0.0002 \mathrm{M}$ (cal.) solution.

\section{Standard sodium sulphide solution}

Weighed amount, $0.2 \mathrm{~g}$ of sodium sulphide was transferred into a clean $150 \mathrm{~mL}$ beaker. It was dissolved in about $50 \mathrm{~mL}$ of water and then transferred the solution in to a $100 \mathrm{~mL}$ volumetric flask. The beaker was washed 3-4 times with water and washings were also transferred into the same flask and the solution was diluted to the mark with water. The solution was standardized iodimetrically ${ }^{27,28}$ before use.

\section{Procedure}

Construction of the calibration graph.

A series of labeled $10 \mathrm{~mL}$ volumetric flasks were arranged. $1.5 \mathrm{~mL}$ of $0.0002 \mathrm{M} \mathrm{Mn}(\mathrm{III})$ solution was added to each flask. A known but various volumes, $0.1-0.7 \mathrm{~mL}$ of standard sodium sulphide $\left(20 \mu \mathrm{g} \mathrm{mL}^{-1}\right)$ solutions were added to each flask and the solutions were kept aside for about $5 \mathrm{~min}$ to ensure the completion of reaction. Then, $1.0 \mathrm{~mL}$ of standard $o$-tolidine $(0.0001 \mathrm{M})$ solution was added to each flask and the solution in each one of them was diluted to the mark with water. The solutions were mixed well and kept aside for about $10 \mathrm{~min}$. The absorbance of each solution was measured at $455 \mathrm{~nm}$ against water. The calibration graph obtained from the values is given in Figure 1.

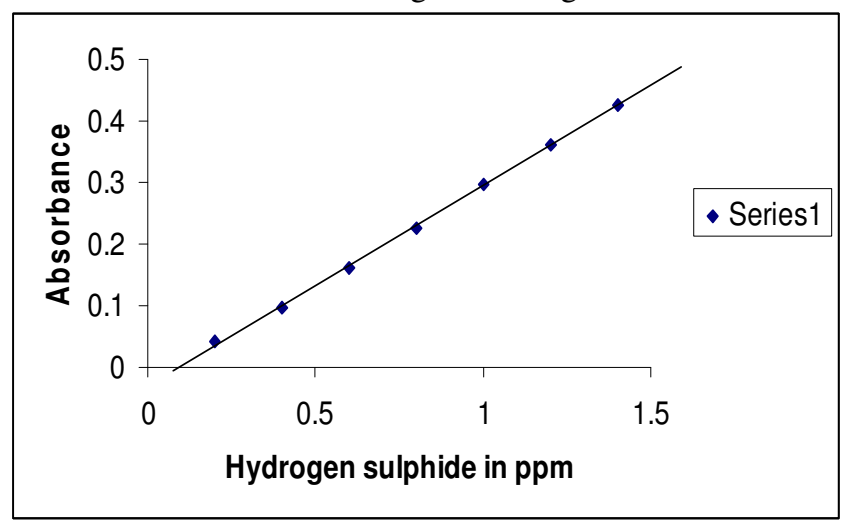

Figure 1. Calibration graph for the determination of Hydrogen sulphide under optimized experimental condition 


\section{Results and Discussion}

The method is based on a redox reaction in that $\mathrm{Mn}$ (III) generated electrolytically ${ }^{23-24}$ is taken in excess, which is oxidizing a known but very less quantity of hydrogen sulphide, then the unreacted oxidant will oxidize further o-tolidine to an orange yellow, quinonediimine absorbing cation ${ }^{25}$. Therefore, in principle, the decrease in color intensity of the absorbing system in that condition is proportional to the concentration of hydrogen sulphide. The color of the system was found to be stable for more than $2 \mathrm{~h}$. The linear decrease in absorbance of the system was measured at $455 \mathrm{~nm}$. The system obeys LambertBeer's law, for the determination of hydrogen sulphide in the concentration range 0.2-1.4 $\mu \mathrm{g}$ $\mathrm{mL}^{-1}$. The system, Figure 1 produced a straight line with slope 0.324 and intercept 0.0325 . Molar absorptivity, correlation coefficient and Sandell's sensitivity values were found to be $4.2062 \times 10^{3} \mathrm{~L} \mathrm{~mol}^{-1}, \mathrm{~cm}^{-1}, 0.999$ and $0.0012 \mu \mathrm{g} \mathrm{cm}^{-2}$ respectively. The stoichiometry between the $o$-tolidine and Mn(III) was determined by Job's continuous variation method ${ }^{29}$ and the values were found to be 1:2 with respect to $o$-tolidine and $\mathrm{Mn}(\mathrm{III})$. The stability constant of the system was also calculated and it was found to be $1.42 \times 10^{5} \mathrm{~L} \mathrm{~mol}^{-1}$. The proposed method was applied for the determination of hydrogen sulphide present in water samples Table 1. The results obtained were reproducible with standard deviation 0.01-0.068 and relative standard deviation, less than $3.2 \%$. For a comparison of results, the hydrogen sulphide contents in these samples were also determined separately following the methylene blue official method. ${ }^{30}$ The results so obtained by both the method's as in Table 1 agree with one another. A probable reaction mechanism of the method is also given;

Table 1. Determination of hydrogen sulphide in water samples

\begin{tabular}{lcc}
\hline Sample & Proposed method, $\mu \mathrm{g} \mathrm{mL} \mathrm{L}^{-1}$ & Official method $\mu \mathrm{g} \mathrm{mL}$ \\
\hline Kadakola lake water & 0.210 & 0.212 \\
Karanji lake water & 0.320 & 0.323 \\
Nanjangud lake water & 0.296 & 0.298 \\
Lingabudi lake water & 0.310 & 0.313 \\
Kukkara hally lake water & 0.289 & 0.286 \\
\hline
\end{tabular}

* Hydrogen sulphide in $\mu \mathrm{g} \mathrm{mL}^{-1}$ is mean value of five determinations.
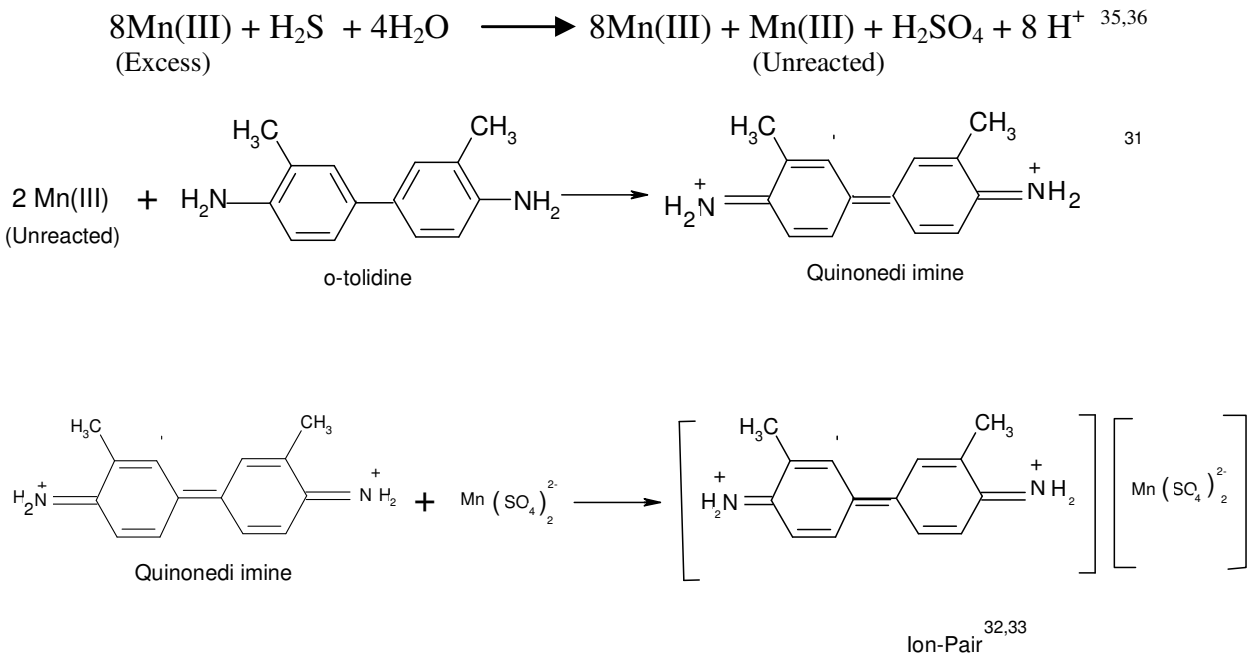


\section{Effect of foreign ions}

For understanding the reaction selectivity, interference of common ions, which often accompany hydrogen sulphide or sulphide were investigated for the determination of $0.8 \mu \mathrm{g} \mathrm{mL}^{-1}$ of hydrogen sulphide under optimum conditions given in the recommended procedure. The results obtained are summarized in Table 2. In the proposed method sulfur dioxide as sodium metabisulphite does not interfere up to $20.934 \mu \mathrm{g} \mathrm{mL}^{-1}$. Nitrite was found to be interfering seriously even at $1.6 \mu \mathrm{g} \mathrm{mL}^{-1}$, but when $1 \mathrm{~mL}$ of $1 \%$ sulphamic acid was added, it could be tolerated up to $5.3224 \mu \mathrm{g} \mathrm{mL}^{-1}$. The tolerance limit is the maximum concentration of that ion where it does not cause more than $4 \%$ error in the determination of hydrogen sulphide, $0.8 \mu \mathrm{g} \mathrm{mL}^{-1}$

Table 2. Interference of foreign ions for the determination of $0.8 \mu \mathrm{g} \mathrm{mL}^{-1}$ of hydrogen sulphide.

\begin{tabular}{cc}
\hline Ion added & Tolerance limit, $\mu \mathrm{g} \mathrm{mL}{ }^{-1}$ \\
\hline $\mathrm{Mg}^{2+}$ & 60.57 \\
$\mathrm{Zn}^{2+}$ & 45.48 \\
$\mathrm{Cd}^{2+}$ & 298.52 \\
$\mathrm{SO}_{4}{ }^{2-}$ & 239.42 \\
$\mathrm{NO}^{2-}$ & 5.3224 \\
$\mathrm{Cl}^{-}$ & 400 \\
$\mathrm{SO}_{2}$ & 20.934 \\
$\mathrm{Fe}^{3+}$ & 20.0 \\
\hline
\end{tabular}

These ions concentrations were examined only up to $400 \mu \mathrm{g} \mathrm{m} L^{-1}$

\section{Determinations of stoichiometry and stability constant}

The composition between $\mathrm{Mn}$ (III) and $o$-tolidine was studied by modified job's method of continuous variation ${ }^{29}$. The concentration of aqueous solutions of $\mathrm{Mn}(\mathrm{III})$ and $o$-tolidine both of them were $0.0001 \mathrm{M}$. Nine solutions were prepared containing $\mathrm{Mn}$ (III) and $o$-tolidine in various molar ratio's so that their volumes were always amounted to $5 \mathrm{~mL}$. The results obtained were used in plotting the graph, Figure 2, that accounts for 2:1 stoichiometry between $\mathrm{Mn}(\mathrm{III})$ and $o$-tolidine respectively. Similarly, the experiment was carried out for other set of solution following the above procedure but with the solutions diluted to $25 \mathrm{~mL}$ instead of $10 \mathrm{~mL}$. The results obtained were used for the construction of the graph (Figure 2), which again accounts for 2:1 stoichiometry between $\mathrm{Mn}(\mathrm{III})$ and $o$-tolidine respectively. The stability constant of the complex was calculated ${ }^{29}$ and it was found to be $1.42 \times 10^{5} 1 \mathrm{~mol}^{-1}$.

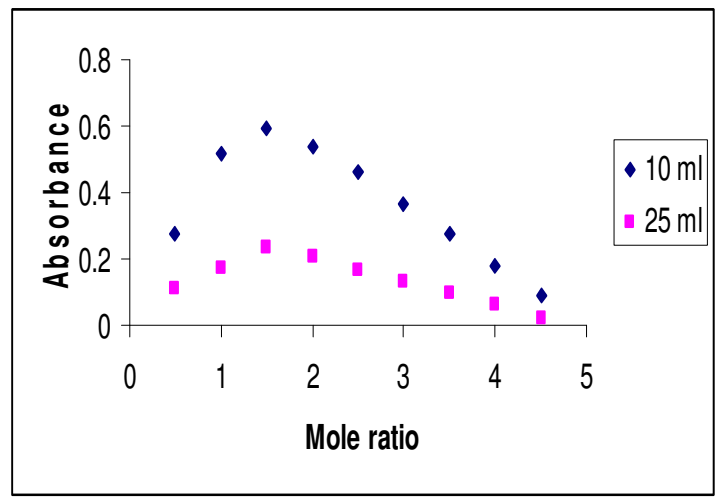

Figure 2. Determination of stoichiometry and stability constant 


\section{Conclusion}

The developed new method was employed effectively for the determination of hydrogen sulphide in water samples. Electrolytically generated $\mathrm{Mn}(\mathrm{III})^{23,24}$ was found to be stable for more than one month. Manganese(III) does not work like iron(III) with o-tolidine in presence of hydrogen sulphide in methylene blue test ${ }^{34}$ instead, under optimized conditions it oxidizes sulphide to sulphate $e^{35,36}$ and o-tolidine to qunonediimine absorbing cation ${ }^{25}$. The developed method is simple, rapid, inexpensive and reliable for the determination of hydrogen sulphide in water samples. Some methods require sophisticated instrumental techniques $^{21-23}$ and solvent extraction using benzene ${ }^{24}$, instead the proposed method is simple, straightforward and yields reliable results. For comparison, hydrogen sulphide present in water samples were also determined separately following the methylene blue official method ${ }^{30}$. The results (Table 1) of the proposed method compare well with the official method.

\section{References}

1. Almy L H, Contributed from the bureau of chemistry, United States department of agriculture, 1925.

2. Sienko M J and Plane A R, Chemical principles and properties, 2nd Ed. Mc Graw Hill publisting Co, New York, NY, 1974.

3. Mckee J E and Wolf H.D, Water quality criteria, 2nd Ed. Resources Agency of California state water resource control Board, 1963.

4. U S Environmental protection agency Quality criteria for water. Washington, D.C. pp. 410, 1976.

5. Thienes H S and Haley T J, Clinicol. toxicology. $5^{\text {th }}$ Ed.. Lea \& Febiger, Philadelplia, PA. 1972.

6. Lang E P, Draize J H, J. Pharmacol. Exp. Ther, 1942, 76, 170.

7. Leithe W, The Analysis of Air pollutants, Ahr arbor Scinece publishers, Ann Aribor. 1971, 143-168.

8. Sawyer C N, Macarty P L and Parkin G F, Chemistry for enviraonmertal engineering, Mc Graw - Hill Inc. New York, 1994, 590.

9. Balasubramanian N and Kumar S M, Analyst, 1990, 115, 859.

10. Ferrer L, Miro M, Estela J M and Cerda V, Treands in Analytical Chemistry, (in press), 2007.

11. Egorova V I, Vasilevs S V and Stolyrovn V S, Zavod Lab, 1991, 57 (3), 18.

12. Abdul wahab S A, Al Hadded A A and Abdo M S E, J. Air. Waste manage Assoc. 1990, 40 (10), 1410.

13. Yamamoto K and Tsuji H, Bunseki Kagaku, 1987, 366 (12) pp 830 - 835 (Anal Abstracts CD. 1985 - 1990),

14. Solitrenick M, Silva P, Cristiane X and Jorge C M G, Talanta, 2003, 60, 45.

15. Verma A K and Gupta Y K, Chem-Anal, 1996, 41 (6), 999.

16. Volberg-NSH A A, Pavlenko and Tr Gl Geofiz ols ion A-I, voeikova, 1989, 521, 38.

17. Sun S and Fenxi-Huaxue, Anal Abstracts, 1988, 16(7), 577 - 580.

18. Kass M and Ivarka A, Analytica. chimica. Acta, 2001, 449, 189.

19. Matheson N A, Analyst (London), 1974, 99, 577.

20. Shanthi K and Balasubramanian N, Anal Abstracts, 1996, 58, (6-8), 647-650, 
21. Lodge $\mathbf{J}$ and Pate $\mathbf{J}$ B, Analysis of air pollutants edited by Kothoff I M, Eiving P J and Stress F H., Treative on analytical chemistry, part III, vol. II, Analytical Chemistry in industry, Wiley, Interscience, New York, 1970.

22. Daniel F L and Robert J E, Environ. Sci. Technol.1976, 2, 159.

23. Rai S K, Shivakumar K and Sherigara B S, European Polymer J. 2000, 36, 1339.

24. Ayesha N M, Anitha N, Rai K M L, Rangappa K S, Trends Carbohydr. Chem. 1999, 4, 109.

25. Jiri Barek, Antonin Berka, Zuzana Tocksteinova and Jiri zina, Talanta, 1986, 33, 811.

26. Jeffery G H, Bassett J, Mendham J and Denney R.C, Vogel's Text book of quantitative chemical Analysis, $5^{\text {th }}$ Ed., Revised by Longman group UK Ltd, 1978 \& 1989.

27. Balasubramanian N and Ramakrishna T V, Indian. J. Chem, 1983, 224, 550.

28. Vogel A I, "A text book of quantitative chemical Analysis $5^{\text {th }}$ ed. Longman's London, 1991

29. Rose J, Advanced Physico Chemical Experiments, published by Sir Issac Pitman and Sons Ltd., London, 1964, 48.

30. Arnold E, Greenberg Lenne S, Clesceri and Andrew D Eaton, Standard methods for the examination of water wastewater, edited by American Public Health Association. $1015,15^{\text {th }}$ street, Washington DC, 2005, pp 4-126-128, $18^{\text {th }}$ Ed.. 1992.

31 Ana-Maria Hossu and Magearuh Roumaniah V, Biological Letters, 2004, 9, 1497.

32. Cotton F A and Wilkinson, Advance Inorganic Chemistry. A comprehensive text, $3^{\text {rd }}$ Ed. Interscience publishers, John Wiley Sons, New York, 1972.

33. Opekar S and Bruckenstein S, Anal. Chem. 1984, 56, 1206.

34. Svehla G, Vogel's Qualitative Inorganic Analysis, $7^{\text {th }}$ Ed. Longman Group limited, 1998, 178.

35. Erwin B Kelsey and Harold G Dietrich, Fundamentals of Semimicro Qualitative Analysis, The Macmillan Co.NY,1940, 280.

36., Harold F Walton, Principles and Methods of Chemical Analysis, $2^{\text {nd }}$ Ed. PrenticeHall of India Pvt. Ltd., New Delhi, 1966,427. 


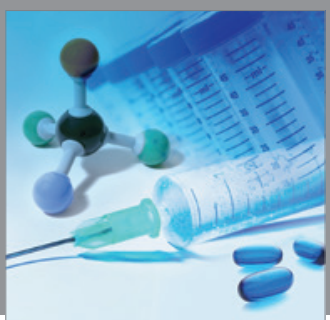

International Journal of

Medicinal Chemistry

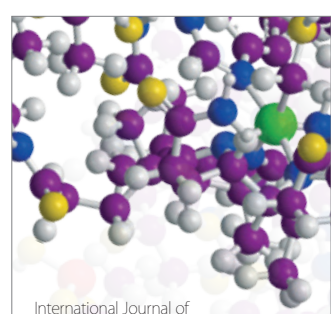

Carbohydrate Chemistry

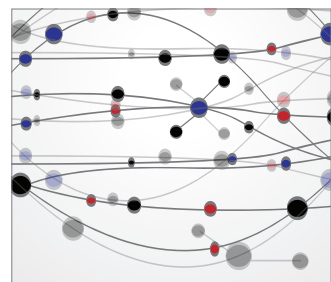

The Scientific World Journal
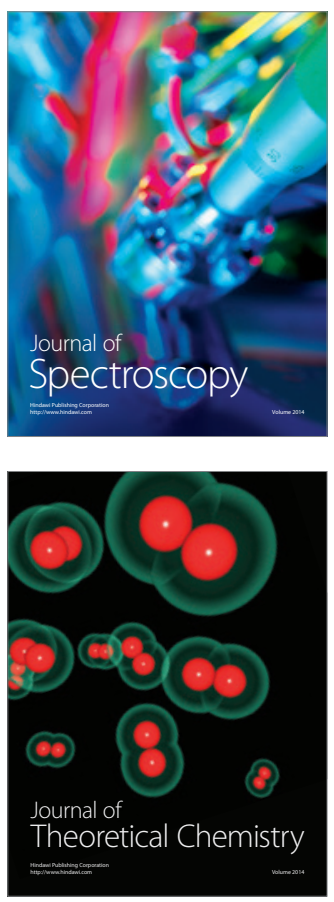
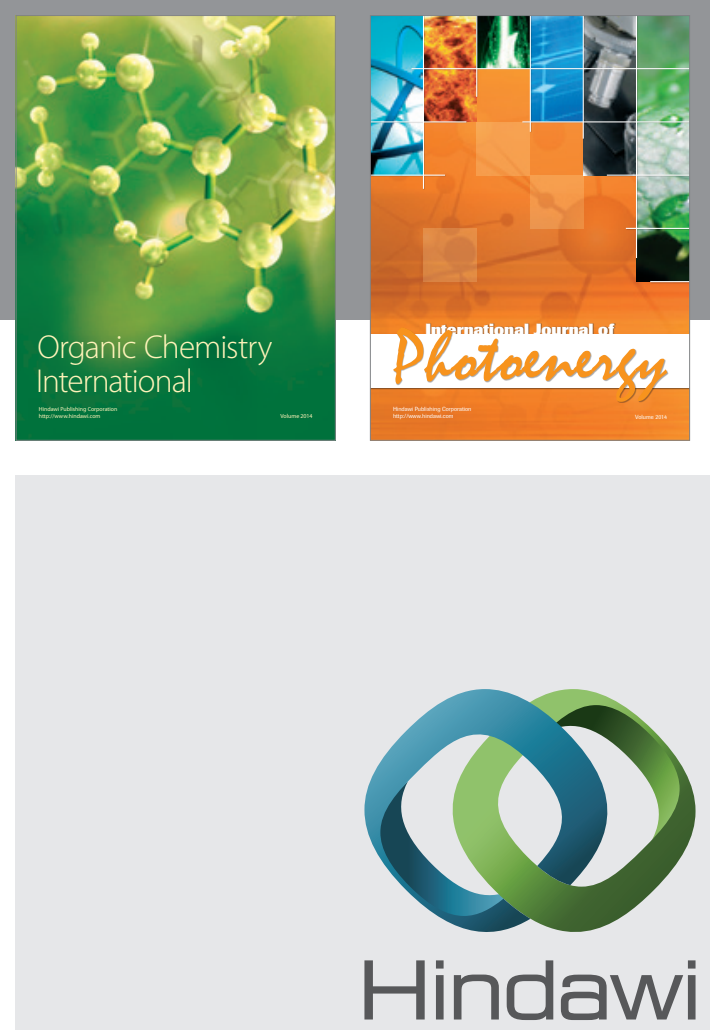

Submit your manuscripts at

http://www.hindawi.com
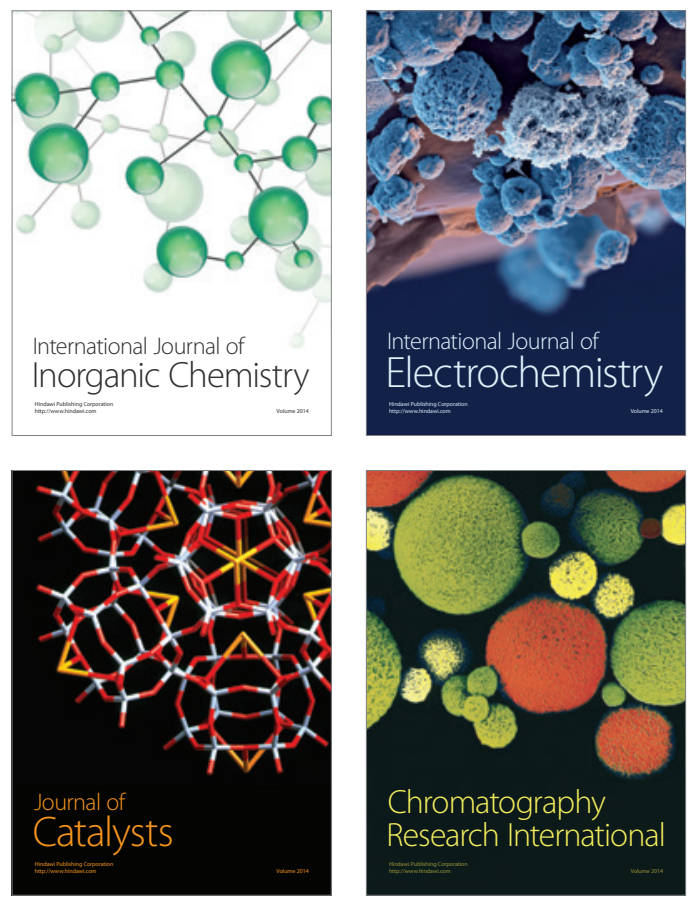
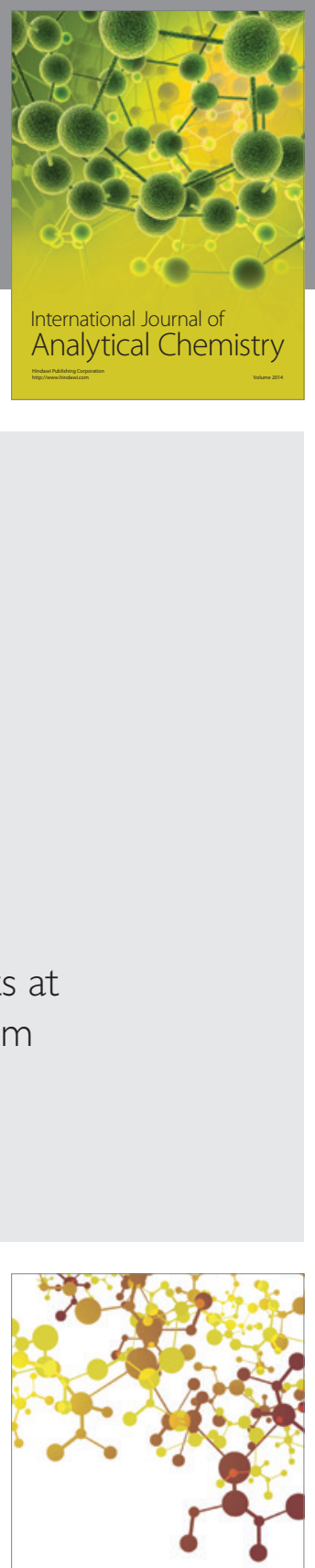

Journal of

Applied Chemistry
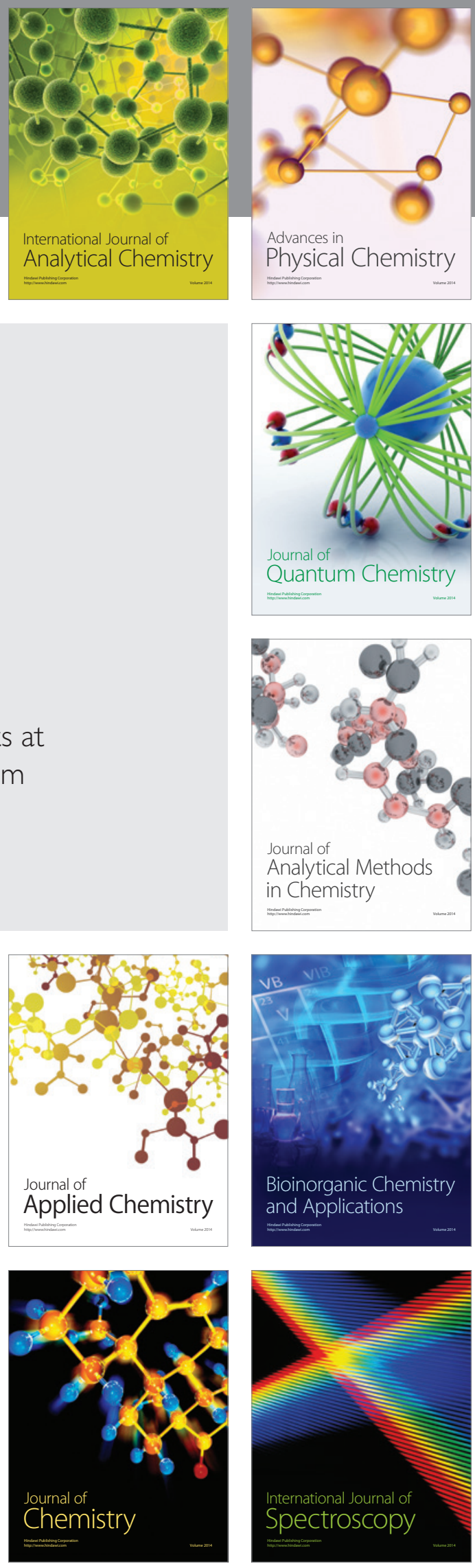